\title{
COMPARISON OF EFFECTIVENESS OF BASIL LEAVES ETHANOL EXTRACT WITH GARLIC ON STAPHYLOCOCCUS AUREUS BACTERIA
}

\author{
Perbandingan Efektivitas Ekstrak Etanol Daun Kemangi Dengan Bawang \\ Putih Terhadap Pertumbuhan Bakteri Staphylococcus Aureus
}

\author{
ELISABETH CHINDY CLARA, NICO MARCELINO, KANIA INDRYANI \\ FAUHAN, ALFI SYAHRI RAHMADHANA, I NYOMAN EHRICH LISTER \\ Study Program of Medical Education, Faculty of Medicine, Univesitas Prima Indonesia, \\ Medan \\ Email: nicomarcelino24@gmail.com
}

\begin{abstract}
Writing the results of the study was conducted to assess the effectiveness comparison of the ethanol extract of basil leaves with garlic with a concentration of 5\%,10\%,15\% of each extract against the growing power of the Staphylococcus aureus bacteria. Staphylococcus aureus bacteria are gram-positive, cocci-shaped bacteria that live in colonies. These bacteria are normal flora in the human body that can harm humans. This study uses an experimental method with a post-test only design and the sample collection used purposive sampling. The effectiveness test was carried out using the disk diffusion method, where the paper disc would be moistened with basil leaves ethanol extract of each concentration, is $5 \%, 10 \%, 15 \%$ and so was the ethanol extract of garlic. The results of the data obtained from this study continued with the Oneway-Anova test which will be continued with the Post-Hoc test, wherein the test there were significant differences from each treatment given. In bacteria treated with ethanol extract $15 \%$ basil leaves against Staphylococcus bacteria aureus, the effectiveness of the inhibition zone was found to be $9.2 \mathrm{~mm}$ in diameter where the inhibition zone was below the ethanol extract of $15 \%$ garlic which was $22.8 \mathrm{~mm}$. Ethanol extract of $15 \%$ garlic has a good antimicrobial effect compared with ethanol extract of basil leaves $15 \%$ against Staphylococcus aureus bacteria.
\end{abstract}

Keywords: Ethanol Extract, Garlic, Basil Leaves, Antibacterial, Staphylococcus aureus

\begin{abstract}
Abstrak Penulisan hasil penelitian tersebut dilakukan untuk menilai perbandingan efektifitas dari ekstrak etanol daun kemangi dengan bawang putih dengan konsentrasi 5\%, 10\%, 15\% dari setiap ekstrak terhadap daya tumbuh bakteri Staphylococcus aureus. Bakteri Staphylococcus aureus ialah bakteri gram positif berbentuk kokus yang hidup berkoloni. Bakteri tersebut merupakan flora normal di tubuh manusia yang dapat membahayakan manusia. Penelitian ini menggunakan metode eksperimen dengan desain post- test only design dan pengambilan sampelnya menggunakan Purposive sampling. Uji efektifitas dilakukan menggunakan metode difusi cakram, dimana kertas cakram akan di basahi dengan ekstrak etanol daun kemangi dari setiap konsentrasi, yaitu 5\%, 10\%, 15\% dan begitu pula ekstrak etanol bawang putih. Hasil data yang diperoleh dari penelitian ini dilanjutkan dengan uji oneway-Anova yang akan diteruskan dengan uji Post-Hoc, dimana pada pengujian terdapat perbedaan yang bermakna dari setiap perlakuan yang diberikan. Pada bakteri yang diberi perlakuan ekstrak etanol daun kemangi $15 \%$ terhadap bakteri Staphylococcus aureus, efektifitas zona hambat didapati berdiameter 9,2 mm dimana zona hambatnya berada dibawah ekstrak etanol bawang putih $15 \%$ yaitu 22,8mm. Ekstrak etanol bawang putih $15 \%$ memiliki efek antimikroba yang baik dibandingkan dengan ekstrak etanol daun kemangi 15\% terhadap bakteri Staphylococcus aureus.
\end{abstract}

Kata Kunci: Ekstrak Etanol, Bawang Putih, Daun Kemangi, Anti bakteri, Staphylococcus aureus 



\section{INTRODUCTION}

Garlic has pharmacological effects such as antidiabetic, anti-hypertensive, anti-cholesterol, anti-atherosclerosis, anti-oxidant, anti-platelet cell aggregation, boosters fibrolysis, anti-virus, anti-microbial and anti-cancer (Hernawan, 2014). One of the anti-microbial pharmacological effects is on gram-positive and negative bacteria. Garlic has active chemicals such as organosulfur compounds containing amino acids, essential oils or alliin, and allicin. There are also flavonoids and saponins (Pritacindy \& Kurniawan, 2018). The active chemical which has an anti-microbial effectiveness is allisin. It is one of the many active pathogenic bacteria-killing agents (Moulia, Syarief, Iriani, \& Kusumaningrum, 2018). The types of microbes which can be inhibited by garlic (Allium sativum L.) are: antibacterial, for example Staphylococcus aureus, $\alpha$ and $\beta$ hemolytic streptococcus, Eschericia coli, and Proteus vulgaris, antifungal, such as Candida ablicans, viruses, such as Herpes, and protozoa for example Trypanosoma brucei. Garlic can be used in several forms, for example garlic drink, garlic essential oil and garlic extract. The variety of garlic is quite diverse, as is often found in Indonesian traditional markets, which are varieties of sin chung and kating (Windrasari, 2016). The difference which can be assessed from each variation of garlic is the smell produced. Sin chung garlic is less flavorful compared to kating garlic (Moulia et al., 2018).

Other plants which are also easy to find is basil. This plant is a wild plant which is not difficult to grow in the wild and it is usually cultivated especially by Indonesian people. Traditionally, the basil plant is used to treat colic, fever, eliminate bad breath, and as a vegetable. Basil has active substances such as oil Linalool, 1,8-cineol, Eugenol, Methyl cinnamate, $\alpha$-cubebene, caryophyllene, $\beta$ ocimene and $\alpha$-farnesene (Salsabila Zahra \& Yoppi Iskandar, 2017). Basil also has an effect, antibacterial, antidiabetic and antihyperglycemic and antioxidant effectiveness. These basil plants contain compounds of alkaloids, flavonoids, phenols, saponins, tannins and steroids that are antibacterial (Chandra, Sari, Misfadhila, Azizah, \& Asra, 2019). The content of flavonoids works by destroying the cell wall of bacteria which results in cell death and inhibits the process of protein synthesis that is similar to the mechanism of action of antibiotics (Threenesia, 2017). In addition to the flavonoid content, the phenol content also has an antibacterial mechanism by removing cations and macromolecules from cells. Thus, the growth of cells will be disrupted and may die (Larasati \& Apriliana, 2016).

Bacterial infections generally occur in various environments, and it can be found in the human body in general such as, on human skin, nails, nose, and mucous membranes. It is called Staphylococcus aureus bacteria. Staphylococcus aureus is a round grampositive bacterium with a diameter of 0.7-1.2 $\mu \mathrm{m}$ (Rahmi et al., 2015). The nature of these bacteria is non-motile, nonporous, facultative anaerobes, positive catalase and negative oxidase. This bacterium can grow at $6.5 \mathrm{oC}$ with a $\mathrm{pH}$ of 4.2-9.3. Transmission of these bacteria by direct physical contact or through the air. Staphylococcus aureus infection can occur on the surface of the skin, wounds, and deeper tissues to cause infections such as acne (acne), abscesses, pneumonia, meningitis, and arthritis (S. Brooks, Geo F. Butel, janet. Morse, 2004).

\section{RESEARCH METHOD}

This research used experimental research with research design of ONE-WAY ANOVA. Furthermore, it is continued with the Post-Hoc test research design. This research used a quantitative approach to test hypotheses from data which had been collected.

The tools used in this research were Oven, Blender, Scales, Syrup Bottles, Plastic Jars, Medium-sized Funnels, Cloth Sieves, 2 L Deregents, Stirring Bars, Measuring Cups, Baker Glass, Magnetic Stirrer Hotplate, Rotary Vaccum Evaporator, Alumium Foil, Plastic Wrap, $10 \mathrm{~mL}$ Measuring Pumpkin, Dropper Pipette, Micro Pipette, Reaction Tubes, Ose Rods, Spiritus Lamps, Petri Dish, Markers, Label Paper, Sterile Swab Sticks, Tweezers, Paper Discs, Incubators, Autoclaves, Plastic Glass 40 x 60 .

The materials used for this research were 23000 grams (23 kg) of Basil, 12000 grams (12 $\mathrm{kg}$ ) of Garlic, 96\% Ethanol, Ciprofloxacin Disc Paper, Aquabidest, Aquadest, Nutrient Agar, Nutrient Broth, Staphylococcus aureus Bacteria.

Method of basil leaves extraction used in this research was maceration technique. $96 \%$ ethanol was used as a solvent in the maceration technique in this research. 100 grams of dried 
basil leaves were macerated with $96 \%$ ethanol as much as $400 \mathrm{~mL}$, then stirred and allowed to stand for 72 hours at room temperature. Furthermore, the ethanol extract of basil leaves was carried out and the results of the solvent were evaporated using a rotary evaporator. The extract which had been obtained is then placed on a Hotplate Magnetic Stirer until the extract was obtained with a thick consistency.

While the garlic extraction method used in this research was maceration technique. This was used because the maceration technique was the simplest screening technique (Indraswari, 2008). In this research, $96 \%$ ethanol was used as a solvent. This was because ethanol had a good attractiveness of active ingredients in an extract compared to other solvents (Prasonto, Riyanti, \& Gartika, 2017). The dried garlic powder which had been obtained was then taken 200 grams and then soaked in $500 \mathrm{ml}$ of $96 \%$ ethanol for 2 days. After that, it was filtered using a filter cloth to take the filtrate from garlic extract. Stirring on the maceration method was carried out using a Hotplate Magnetic Stirer until the extract thickens. Furthermore, the extract was evaporated with a rotary vacuum evaporator until thick.

Making the concentration using ethanol extract of basil leaves and ethanol extract of garlic were $5 \%, 10 \%, 15 \%$. Making the concentration used a measuring flask measuring $10 \mathrm{~mL}$. Making the concentration of ethanol extract of basil leaves $5 \%$ was conducted by the dilution formula of $0.5 \mathrm{~mL}$ of basil or garlic extracts dissolved together with aquadest by measuring pumpkin media measuring $10 \mathrm{~mL}$.

The first step was to take $500 \mu \mathrm{L}$ of basil leaves ethanol extract using a micro pipette, then put into a $10 \mathrm{~mL}$ measuring flask, then use a dropper pipette, take the aquadest then put it in the flask until it reaches the white line on the measuring flask. After that close the measuring flask, then homogenize by turning the wrist up and down until the mixture is evenly distributed. Next, pour the homogeneous solution into the test tube. The same was carried out with other concentrations and with ethanol extract of garlic.

Making media was carried out by using Nutrient Agar (NA) due to nutrient agar because the media used had to be rich in nutrients such as carbohydrates and protein (Khaerunnisa, Kurniati, Nurhayati, \& Dermawan, 2019). Prepare 18 petri disks (petri dishes). In one Petri dish, it was filled with 28 grams of media in $1000 \mathrm{ml}$ of distilled water, then heated while stirring until the media dissolves then sterilized in an autoclave at $121^{\circ} \mathrm{C}$ for 15 minutes. Sterile media was cooled to room temperature, then poured into a petri dish.

Media used was Nutrient Broth (NB). weigh 8 grams in $1000 \mathrm{ml}$ of distilled water, then heat while stirring using a hotplate magnetic stirer until homogeneous. Then prepare a test tube to be sterilized with NB media in an autoclave at $121^{\circ} \mathrm{C}$ for 15 minutes. After that, the media and the sterile tube were cooled to room temperature, then NB media was poured into the test tube as much as $10 \mathrm{ml}$. In addition, the Staphylococcus aureus bacterial isolet was taken by using sterile ose, then put in a test tube containing NB media, then stirred until homogeneous. Then, the liquid isolate was incubated for 24 hours in an incubator at $37^{\circ} \mathrm{C}$.

After the process of making ethanol extract concentrations of basil and garlic leaves, the results obtained were then tested for the effectiveness of the extract using diffuse discs. Process of effectiveness test of basil leaves extract

1. The first step is take the NA media which has been given a concentration label first, then take the Staphylococcus aureus culture using a sterile swab stick, then rub it across the entire NA media field until it is evenly distributed then closed again. Furthermore, burn the stick swab and throw it into the infectious trash.

2. The next step is to take a blank disc using tweezers, then put it into the basil leaves ethanol extract solution with the smallest concentration of $5 \%$. Then drain and after it is planted into NA media, repeat until the highest concentration of $15 \%$. After the extraction process, all NA media were covered using plastic wrap, then put in an incubator at $37^{\circ} \mathrm{C}$ and left up to $2 \times 24$ hours, to see how much the inhibition zone produced by each extract concentration on the growth of Staphylococcus aureus bacteria.

3. And the final step to do is to measure the diameter of the inhibitory zone obtained around the paper discs using sliding bars.

Data obtained from the results of antibacterial activity testing were then analyzed with SPSS software using the Oneway-Anova test, then the Post-Hoc test.Ho: There is no 
difference in the sensitivity test of the Basil Leaves Ethanol Extract with the Garlic Ethanol Extract toward the Growth of Staphylococcus aureus Bacteria.

$\mathrm{H} \alpha$ : There is a difference in the sensitivity test of the Basil Leaves Ethanol Extract and the Garlic Ethanol Extract toward the Growth of Staphylococcus aureus Bacteria.

Taking data was conducted in August 2019 at USU Laboratory and in Septermber 2019 at UNPRI Laboratory. The samples used were Ethanol Extract from Basil (Ocimum sanctum L.) against Staphylococcus aureus bacteria and Ethanol Extract from Garlic (Allium sativum L.) against Staphylococcus aureus bacteria. From the data which had been collected and then analyzed, it can be concluded the results of the research are shown below.

\section{RESULT AND DISCUSSION}

Test results of basil's leaf phytochemical with positive ethanol solvent contained alkaloids, flavonoids, and glycosides. From the observations, the alkaloid test results with bouchardart reagents found a change in color to brown with a positive meaning, and with maeyer reagents found a change in color to light blue which was positive. Flavonoid test results with $\mathrm{H} 2 \mathrm{SO} 4$ reagents found a change in color to yellowish Green which showed positive results, and the results of the glycoside test with Mollish reagents found a change in color to dark green which indicated positive results.

Table 1. Phytochemical Test Result of Ethanol Extract of Basil' Leaf (Ocimum sanctum $(L)$ )

\begin{tabular}{ccc} 
Extract & $\begin{array}{c}\text { Phythochemical } \\
\text { Test }\end{array}$ & Result \\
\hline \multirow{5}{*}{ Basil Leaf } & Alkaloids & $(+)$ \\
& Steroids \& & $(-)$ \\
& Triterpenoids & $(-)$ \\
& Saponins & $(+)$ \\
& Flavonoids & $(-)$ \\
& Tanins & $(+)$ \\
\hline
\end{tabular}

Phytochemical test results of garlic with positive ethanol solvents contained alkaloid compounds, saponins, flavonoids and glycosides. From the observations, Alkaloid test results with bouchardart reagents the formation of a brick red color showed positive results, Saponin test results with Aquadest reagents indicated a change in color to clear indicating positive results, Flavonoid test results with $\mathrm{Mg}+\mathrm{HCl}$ reagents appeared to have a change in color to light yellow which showed a positive meaning, and the results of the Glycoside test with Mollish reagents, it appeared to be a change in the color of the light yellow shows a positive meaning.

Table 2. Phytochemical Test Result of Ethanol Extract of Garlic (Allium sativum $(L)$ )

\begin{tabular}{ccc} 
Extract & $\begin{array}{c}\text { Phythochemical } \\
\text { Test }\end{array}$ & Result \\
\hline \multirow{6}{*}{ Garlic } & Alkaloids & $(+)$ \\
& Steroids \& & $(-)$ \\
& Triterpenoids & $(+)$ \\
& Saponins & $(+)$ \\
& Flavonoids & $(-)$ \\
& Tanins & $(+)$ \\
\hline
\end{tabular}

Inhibition zone diameter was produced by ethanol extract of basil leaves and ethanol extract of garlic against Staphylococcus aureus bacteria. The inhibitory power produced by the Ethanol Extract from the Basil Leaf using a sensitivity test showed that there was a inhibitory zone (clear zone) around the paper disc. It had been given a concentration. The inhibition zone measurement was conducted by using a calipers by measuring the vertical portion then the measurement results are seen. It is carried out in each treatment. Thus, the inhibition zone was obtained as illustrated and the table below. This test was repeated three times with Ciprofloxacin Antibiotics as Control (+) and Aquadest as Control (-).

Figure 1. Diameter of Inhibitory Zone of Basil Leaf's Ethanol Extract.

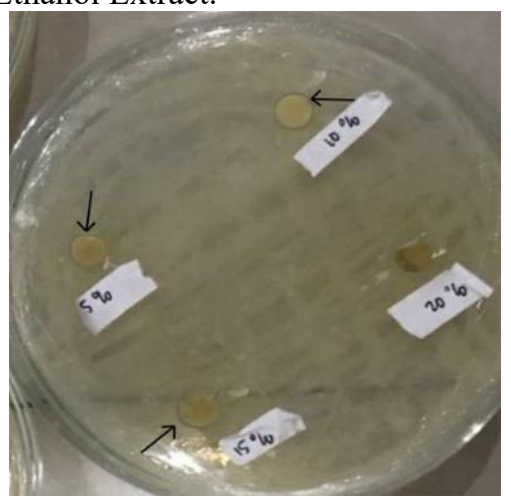


Figure 2. Diameter of Inhibitory Zone of Ciprofloxacin as positive control.

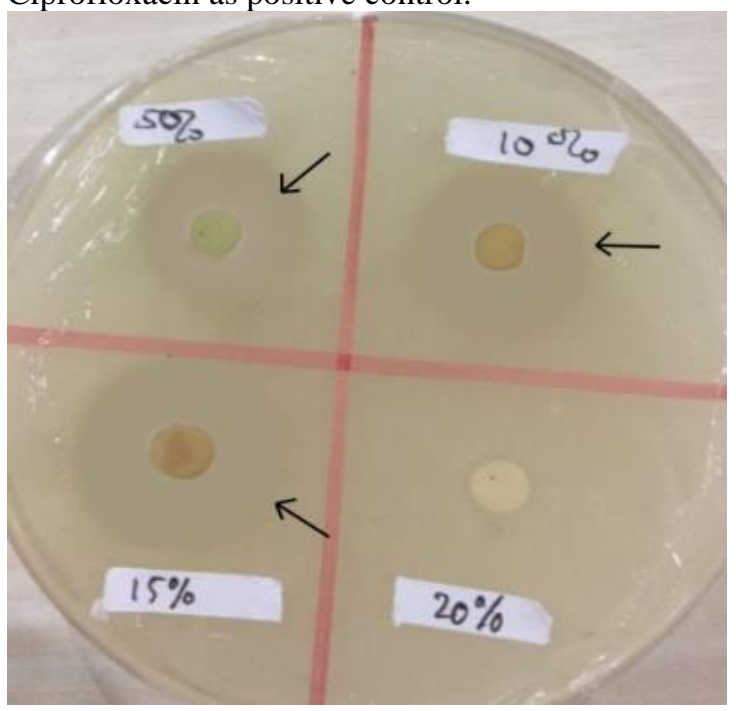

Table 3. Diameter Result of Inhibitory Zone of Ethanol Extract of Basil's Leaf (Ocimum sanctum $(L))$

\begin{tabular}{cccc}
\hline Repeat & $\mathbf{1}$ & $\mathbf{2}$ & $\mathbf{3}$ \\
\hline BLEE 5\% & $8,15 \mathrm{~mm}$ & $6,2 \mathrm{~mm}$ & $6,3 \mathrm{~mm}$ \\
BLEE & $8,4 \mathrm{~mm}$ & $7,9 \mathrm{~mm}$ & $7,75 \mathrm{~mm}$ \\
$10 \%$ & & & \\
BLEE & $9,2 \mathrm{~mm}$ & $8,5 \mathrm{~mm}$ & $8,2 \mathrm{~mm}$ \\
$\begin{array}{c}15 \% \\
\text { Control } \\
(+)\end{array}$ & $27,85 \mathrm{~mm}$ & $27,85 \mathrm{~mm}$ & $27,85 \mathrm{~mm}$ \\
$\begin{array}{c}\text { Control }(- \\
)\end{array}$ & 0 & 0 & 0 \\
\hline
\end{tabular}

Figure 3. Diameter of Inhibitory Zone of Garlic's Ethanol Extract.

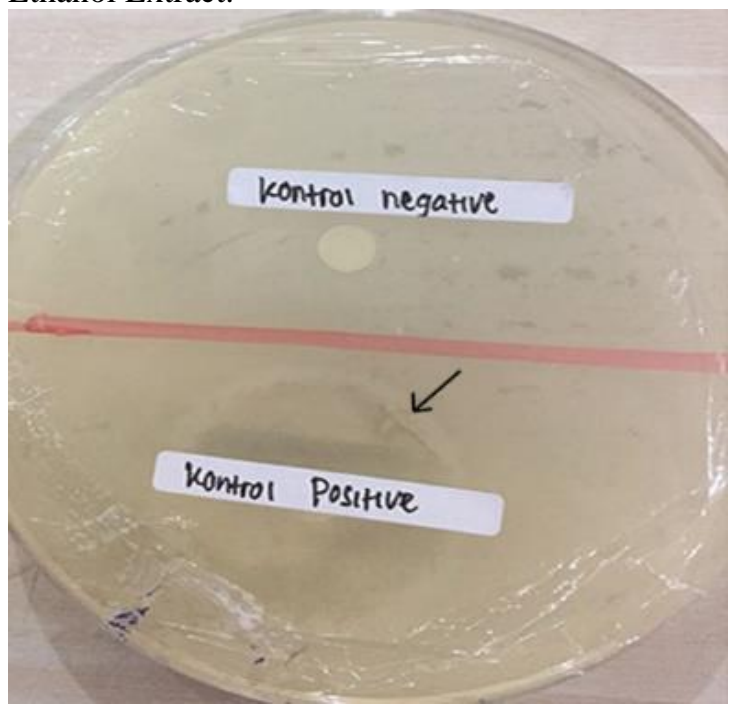

Table 4. Diameter Result of Inhibitory Zone of Ethanol Extract of Garlic (Allium sativum $(L)$ )

\begin{tabular}{cccc}
\hline Repeat & $\mathbf{1}$ & $\mathbf{2}$ & $\mathbf{3}$ \\
\hline GEE 5\% & $10,9 \mathrm{~mm}$ & $15,8 \mathrm{~mm}$ & $20,85 \mathrm{~mm}$ \\
GEE 10\% & $15,3 \mathrm{~mm}$ & $17,5 \mathrm{~mm}$ & $21,8 \mathrm{~mm}$
\end{tabular}

\begin{tabular}{cccc} 
GEE $15 \%$ & $17,8 \mathrm{~mm}$ & $20,75 \mathrm{~mm}$ & $22,8 \mathrm{~mm}$ \\
$\begin{array}{c}\text { Control } \\
(+)\end{array}$ & $27,85 \mathrm{~mm}$ & $27,85 \mathrm{~mm}$ & $27,85 \mathrm{~mm}$ \\
$\begin{array}{c}\text { Control }(- \\
)\end{array}$ & 0 & 0 & 0 \\
\hline
\end{tabular}

From the One Way Anova test results, it was obtained a $\mathrm{P}$ value $=0,000$ which means that $\mathrm{p}<\alpha$ where $\alpha<0.05$. thus, Ha is accepted and Ho is rejected. Furthermore, it can be concluded that there is a difference in the sensitivity test of basil leaf ethanol extract with ethanol extract of garlic toward the growth of Staphylococcus bacteria aureus.

After the One Way Anova test, it was continued using the Post-Hoc test. In this test, it was found a significant difference from each treatment given with a confidence index of $95 \%$.

\section{DISCUSSION}

Based on the result of research data obtained, there was the effectiveness of ethanol extract of basil leaves toward Staphylococcus aureus bacteria and there were differences in the effectiveness of ethanol extract of garlic toward Staphylococcus aureus bacteria. The effectiveness shown was the presence of inhibitory zones formed around disc paper. The inhibition zone was then measured using a calipers to assess the effectiveness of each extract produced against the Staphylococcus aureus bacteria.

To assess how effective the ethanol extract of basil leaves and ethanol extract of garlic could use the Greenwood classification as in the table below.

Table 5. Classification of Bacteria Growth Inhibition Respons

\begin{tabular}{cc}
\hline $\begin{array}{c}\text { Average Diameter of } \\
\text { Inhibitory Zones }\end{array}$ & $\begin{array}{c}\text { Growth Inhibiton } \\
\text { Respons }\end{array}$ \\
\hline$>20 \mathrm{~mm}$ & Strong \\
$16-20 \mathrm{~mm}$ & Medium \\
$10-15 \mathrm{~mm}$ & Weak \\
$<10 \mathrm{~mm}$ & Not Effective \\
\hline
\end{tabular}

Sources:(Firdaus, 2014)

In this research, ethanol extract of basil leaved toward Staphylococcus aureus had an inhibitory zone with an average diameter less than $10 \mathrm{~mm}$. It indicated that the ethanol extract 
of basil leaves is less effective against Staphylococcus aureus bacteria. This might be due to the reduced quality of the ethanol extract of basil leaves.

At the same time, in garlic ethanol extract, the best concentration of inhibition toward Staphylococcus aureus was $15 \%$. This was because the ethanol extract of garlic contained alliin which caused a reduction in cysteine in the bacterial tubules. Thus, the disulfide bonds in the protein were disrupted (1). The best results were found in the third repetition in which it was found zone diameter of $22.8 \mathrm{~mm}$ which was categorized as strong inhibition zone and $5 \%$ concentration in ethanol extract of garlic was the worst concentration. This can be seen from the first repetition in which the inhibition zone diameter produced was only 10 $.9 \mathrm{~mm}$. It was categorized as weak inhibition zones.

In the control (+) used was Ciprofloxacin. It was found that the diameter of the inhibition zone was $27.85 \mathrm{~mm}$ which included a strong inhibition zone. This was because ciprofloxacin could inhibit DNA replication from microbes by blocking DNA synthesis initiated by inhibition of topoisomerase II and topoisomerase IV (Mutiarasari, 2019). and the control (-) used was aquadest which did not show a zone of inhibition against Staphylococcus aureus.

\section{CONCLUSION}

Ethanol extract of basil leaves is less effective in inhibiting Staphylococcus aureus bacterial growth while ethanol extract of garlic has antibacterial effectiveness toward Staphylococcus aureus bacteria. Based on the inhibition zone classification, ethanol extracts of basil leaves have an ineffective inhibitory response to the growth of Staphylococcus aureus bacteria, the best concentration id $15 \%$ with an average inhibition zone diameter of $9.20 \mathrm{~mm}$. Based on inhibition zone classification, ethanol extract of garlic has a strong inhibitory response to the growth of Staphylococcus aureus bacteria, the best concentration is $15 \%$ with an average inhibition zone diameter of $22.8 \mathrm{~mm}$.

From the results of the analysis using the One Way Anova test followed by Post-Hoc test, it was found that the value of $\mathrm{P}=0,000$ was observed that $\mathrm{P}<\alpha$ where $\alpha<0.05$ so Ha was accepted and Ho was rejected, where there was a difference in sensitivity test of ethanol extract of basil leaves with ethanol extract garlic against the growth of Staphylococcus aureus bacteria.

\section{ACKNOWLEDGMENT}

Researcher and research team give their gratitude to Dr. dr. I Nyoman Erich Lister, M. Kes., AIFM as Chair of the Prima Indonesia University Foundation and as a Supervising Lecturer, Dr. Chrismis Novalinda Ginting, M.Kes as Chancellor of the University of Prima Indonesia, and Dr. Linda Chiuman, M.K.M., AIFO-K as the Dean of the Faculty of Medicine, who has facilitated the form of facilities and infrastructure so that this research can be completed well. The researcher also thanks Ditha Paramitha as a Laboratory Assistant of Prima Indonesia University.

\section{REFERENCE}

Chandra, B., Sari, R., Misfadhila, S., Azizah, Z., \& Asra, R. (2019). Skrining Fitokimia dan Aktivitas Antioksidan Ekstrak Metanol Daun Kemangi (Ocimum tenuiflorum L.) Dengan Metode DPPH (1,1-difenil-2-pikrilhidrazil). Journal of Pharmaceutical and Sciences (Jps), 2(2), $1-8$.

Firdaus, T. (2014). Efektifitas ekstrak bawang dayak (Eleutherine palmifolia) dalam menghambat pertumbuhan bakteri Staphylococcus aureus. Jakarta, (1), 150.

https://doi.org/http://repository.uinjkt.ac.i d/dspace/bitstream/123456789/27277/1/ TAZKIYATUL \%20FIRDAUSFKIK.pdf

Hernawan, U. (2014). Senyawa Organosulfur Bawang Putih ( Allium sativum L .) dan Aktivitas Biologinya Aktivitas Biologinya. Biofarmasi Jurusan Biologi FMIPA UNS, 1(August 2003), 64-76.

Indraswari, A. (2008). OPTIMASI PEMBUATAN EKSTRAK DAUN DEWANDARU (Eugenia uniflora L.) MENGGUNAKAN METODE MASERASI DENGAN PARAMETER KADAR TOTAL SENYAWA FENOLIK DAN FLAVONOID. Fakultas Farmasi Universitas Muhammadiyah Surakarta Surakarta, 5-8.

Khaerunnisa, R., Kurniati, I., Nurhayati, D., \& Dermawan, A. (2019). PEMANFAATAN AIR REBUSAN UMBI KUNING DAN UNGU SEBAGAI MEDIA 
ALTERNATIF PERTUMBUHAN

Escherichia coli DAN Staphylococcus aureus. Jurnal Riset Kesehatan Poltekkes Depkes Bandung, 11(1), 269-276.

Larasati, D. A., \& Apriliana, E. (2016). Efek Potensial Daun Kemangi ( Ocimum basilicum L .) sebagai Pemanfaatan Hand Sanitizer The Potential Effect of Basil Leaves ( Ocimum basilicum L .) as Utilization of Hand Sanitizer. Majority, 5(5), 124-129. Retrieved from http://webcache.googleusercontent.com/s earch?q=cache:YrD2YlWQUfEJ:juke.ke dokteran.unila.ac.id/index.php/majority/a rticle/viewFile/936/769+\&cd=1\&hl=en\& $\mathrm{ct}=\mathrm{clnk} \& \mathrm{gl}=\mathrm{id}$

Moulia, M. N., Syarief, R., Iriani, E. S., \& Kusumaningrum, H. D. (2018). Antimikroba Ekstrak Bawang Putih. Antimikroba Ekstrak Bawang Putih Antimicrobial of Garlic Extract, 55-66.

Mutiarasari, D. (2019). MEDIKA TADULAKO , Jurnal Ilmiah Kedokteran , Vol . 1 No . 2. Jurnal Ilmiah Kedokteran, $1(2), 36-44$.

Prasonto, D., Riyanti, E., \& Gartika, M. (2017). UJI AKTIVITAS ANTIOKSIDAN EKSTRAK BAWANG PUTIH (Allium sativum). ODONTO: Dental Journal, 4(2), 122. https://doi.org/10.30659/odj.4.2.122-128

Pritacindy, A. prilly, \& Kurniawan, supriyadi A. (2018). Uji Efektifitas Ekstrak Bawang Putih (Allium Sativum) Sebagai Insektisida Terhadap Kutu Rambut (Pediculus Capitis). The Indonesian Journal of Public Health, 2(1), 1-9.

Rahmi, Y., Darmawi, D., Abrar, M., Jamin, F., Fakhrurrazi, F., \& Fahrimal, Y. (2015). IDENTIFIKASI BAKTERI Staphylococcus aureus PADA PREPUTIUM DAN VAGINA KUDA (Equus caballus) (Identification of Staphylococcus aureus in Preputium and Vagina of Horses (Equus caballus)). Jurnal Medika Veterinaria, 9(2). https://doi.org/10.21157/j.med.vet..v9i2.3 805

S. Brooks, Geo F. Butel, janet. Morse, S. A. (2004). Jawetz, Melnic \& Adelberg Mikrobiologi Kedokteran (23rd ed.). Jakarta: Buku Kedokteran EGC.

Salsabila Zahra \& Yoppi Iskandar. (2017). Review Artikel: Kandungan Senyawa Kimia dan Bioaktivitas Ocimum
Basilicum L. Salsabila. Jurnal Farmaka, 15(3), 143-152.

Threenesia, A. (2017). PERBANDINGAN EFEK PEMBERIAN EKSTRAK ETANOL DAUN KEMANGI (Ocimum sanctum L.) TERHADAP DAYA HAMBAT PERTUMBUHAN staphylococcus aureus dan salmonella typhi SECARA In Vitro. Bandar lampung.

Windrasari, C. (2016). AKTIVITAS ANTIBAKTERI SARI BAWANG PUTIH (Allium sativum Linn. ) KATING DAN SIN CHUNG TERHADAP PERTUMBUHAN BAKTERI Pseudomonas aeruginosa PERUSAK IKAN AIR TAWAR. 